\title{
The Analysis of Test Anxiety Among Students at School of Physical Education and Sports in Terms of Demographic Variables
}

\author{
Çağdaş Caz ${ }^{1}$, Oktay Çoban ${ }^{1} \&$ Mehmet Yıldırım ${ }^{1}$ \\ ${ }^{1}$ School of Physical Education and Sports, Yozgat Bozok University, Yozgat, Turkey \\ Correspondence: Çağdaş Caz, School of Physical Education and Sports, Yozgat Bozok University, Turkey. \\ E-mail: cazcagdas@gmail.com
}

Received: December 11, 2018

Accepted: January 3, 2019 Online Published: January 17, 2019

doi:10.5539/jel.v8n1p214

URL: https://doi.org/10.5539/jel.v8n1p214

\begin{abstract}
The present study aims to measure levels of test anxiety among students studying at different departments at School of Physical Education and Sports. The population of the study consists of 780 students studying at different departments at School of Physical Education and Sports at Yozgat Bozok University during 2018-2019 academic year. The sample of the study consists of 382 students who study at different departments at School of Physical Education and Sports at Yozgat Bozok University during 2018-2019 academic year and voluntarily participated in the online survey sent them by e-mail. Survey was used as a method in the present study, and demographic variables were obtained using "personal information form". "Westside test anxiety scale", which was adapted to Turkish context and tested for reliability and validity by Totan and Yavuz (2009), was used to determine students' level of test anxiety. The obtained data were statistically analyzed using SPSS 18 software program. Frequency analysis, percentage analysis, arithmetic means, $t$ test and ANOVA analysis were used for data analysis. The analyses demonsrate that no statistically significant differences were observed among students' levels of test anxiety in terms of four different variables ( $p>0.05)$. However, as for mean scores, it was found out that female students' level of test anxiety was higher compared to male students. Students studying coaching education had a higher of test anxiety compared to those studying physical education and sports teaching and sports management. In addition, students who did not take notes during lessons had a higher level of test anxiety compared to those who took notes during lessons. Finally, students who reviewed lessons shortly before the test had a higher level of test anxiety compared to those who reviewed their lessons on a daily basis.
\end{abstract}

Keywords: physical education, sports, test, anxiety

\section{Introducation}

Anxiety is one of the most popular research topics in psychology. It was first used as a literary, philosophical and religious term, and it started to be used in the field of psychology in the last century. Sigmund Freud is the first scholar to have defined anxiety and explore reasons underlying it (Köknel, 1989). According to Geçtan (1993), anxiety is "a condition that occurs when an organism reacts against dangers disturbing its internal balance or fails in its efforts to rectify the disturbed balance. Spielberger (2010) defines anxiety as a set of observable reactions, and adds that anxiety may lead to negative conditions such as sadness, tension and emotional sensitivity.

Anxiety influences an individual's daily life in different ways, which may sometimes result in uneasiness or increase an individual's performance. However, people usually consider anxiety as a negative factor, and think that it reduces their working performance (Başarır, 1990). Physical indicators such as a high pulse rate, dehydration, muscle strain, and a high respiration rate indicate a high level of anxiety, and they influence mental processes such as problem-solving skills and a lack of concentration (Başarır, 1990). The main problem is the severity and continuity of the anxiety rather than the anxiety itself (Cüceloğlu, 1997).

Unlike general anxiety, people suffer from test anxiety in later periods of their lives, and continue to feel it during their school lives. Education and tests as a process can cause individuals to suffer from anxiety due to their impact on their professions and lives. Test anxiety is defined as a student's emotional reaction towards the test. It is possible to mention test anxiety when an individual constantly thinks about failure in a test and this negative opinion influences that individual's daily activities (Şahin et al., 2006). 
Academic success and activities towards academic activities occupy an important position in an individual's and family's life. In this respect, more and more plans are made in today's world to achieve related goals. Numerous factors influence academic success. Test is one of these factors, and, as a result, an individual is likely to encounter test anxiety throughout their lives. Students', familys' and teachers' expectations, ambitions and goals may lead to a pressure on students, which is one of the leading factors of test anxiety (Aydın \& Bulgan, 2017). It has been reported by various scholars that various factors such as intelligence, abilities (Erözkan, 2004), personal traits, family, school type which a student graduates from or studies at, and working habits (Can, 1992) may influence academic success. Anxienty is considered as a serious problem for university students, which starts with university entrance exam and continues until they graduate from university. An individual's plans about their future during university education and expectations about a higher grand point average result in a higher test anxiety. It forces university students to feel themselves compelled to compete with other students, and ask themselves whether they will be successful, which is a difficult sitation for them (Erözkan, 2004).

It can be argued that students studying at schools of physical education and sports play an important role in the development of a sports culture in the society. The attempts to educate human body for various purposes date back to ancient times as people started to protect themselves against nature, animals and enemies. However, in recent times, these activities were carried out for entertainment and competition. Body movements were arranged in a certain form in line with several rules, which resulted in the birth of sports. The professionalization of sports sciences and physical education programs started in the $19^{\text {th }}$ century. It is divided into different field of specializations and sub-disciplines as physical education and sports, coaching education, sports management and recreation (Wuest \& Bucher, 2006). While physical strength and performance aspects of sports came to the forefront during the early $20^{\text {th }}$ century, the positive impact of sports on mental health, socialization and physical health are well-known in today's world, and it is recommended that people attach importance to sports in their daily lives (Zorba, 2008). As the importance of sports increases for human life, the responsibilities of students studying physical education and sports also increase. Therefore, it is considered that such responsibility causes various anxieties among students such as getting higher grades and graduating from university on time. The present study aims to determine levels of test anxiety among students studying at different departments at School of Physical Education and Sport.

\section{Method}

\subsection{The Population and Sample of the Study}

The population of the study consists of 780 students studying at different departments at School of Physical Education and Sports at Yozgat Bozok University during 2018-2019 academic year. The sample of the study consists of 382 students who study at different departments at School of Physical Education and Sports at Yozgat Bozok University during 2018-2019 academic year and voluntarily participated in the online survey sent them by e-mail.

\subsection{Data Collection Tools}

Because it is a cost-effective, feasible and suitable method when it comes to collecting data from dispersed and large masses in a short period, questionnaire was used as a primary source data collection tool in the present study. There are two parts in the questionnaire form. While participants' personal and social features are identified using limited items in the first part, a 5-point Likert type scale is used in the second part in order to identify participants' levels of test anxiety.

\subsubsection{Westside Test Anxiety Scale}

In the present study, "Westside test anxiety scale" adapted to Turkish context and tested for reliability and validity by Totan and Yavuz (2009) was used to determine students' level of test anxiety. The data collection tool in question is an 11-item scale with a single sub-dimension and responses ranging from "1 (never)" to "5 (always)". A high score represents a high level of test anxiety, whereas a low score represents a low level. Without a certain point of estimation, when the scale is applied to large groups, it can be stated that participants with a standard deviation value of +1 and higher suffer from a high level of test anxiety, while those with a standard deviation value of -1 and lower suffer from a low level of test anxiety. Total reliability of the scale was calculated as .87. In the present study, on the other hand, total reliability coefficient of the scale was calculated as .89. If a reliability coefficient is between .70 and .90 , it can be considered as high (Bagozzi \& Yi, 1988; Nunnally \& Bernstein, 1994). Therefore, it is evident that the scale meets the minimum level required for an internal consistency reliability coefficient. 


\subsection{Data Analysis}

SPSS 18.0 package program was used to analyze the data obtained in the present study. The data obtained from the study group should be prepared for statistical analysis prior to the statistical data analysis, and skewness and kurtosis coefficients should be accurately calculated (Şimşek, 2007, p. 74). If a skewness coefficient is between $(+-2)$ and a kurtosis coefficient is between (+-7), it can be said that a normal data distribution exists (West et al., 1995; Şencan, 2005, p. 376; Şimşek, 2007, p. 74). Skewness and kurtosis coefficients in the present study were calculated as $0.002 / 1.251$ and $-0.437 / 2.843$, respectively. Therefore, the data display a normal distribution, and parametric tests were used for the statistical analysis.

In order to analyze the data obtained from the study, students' demographic features were described using frequency analysis. In addition, $t$ test and ANOVA were used to demonstrate differences among students' levels of test anxiety in terms of demographic variables. The level of statistical significance was taken as 0.05 .

\section{Findings}

The findings related to students' demographic features are given in Table 1.

Table 1. The findings related to students' demographic features

\begin{tabular}{llll}
\hline & & $\mathrm{N}$ & $\%$ \\
\hline Gender & Female & 166 & 43.5 \\
& Male & 216 & 56.5 \\
Department & Physical Education and Sports Teaching & 106 & 27.7 \\
& Sports Management & 150 & 39.3 \\
& Coaching Education & 126 & 33.0 \\
Note-taking during lessons & Yes & 292 & 76.4 \\
& No & 90 & 23.6 \\
Frequency of lesson review & I review my lesson notes on a daily basis & 50 & 13.1 \\
& I review my lessons shortly before the test & 332 & 86.9 \\
\hline
\end{tabular}

When Table 1 is analyzed, it can be seen that 166 students (43.5\%) are females, while 216 of them $(56.5 \%)$ are males. 106 students $(27.7 \%)$ study physical education and sports teaching, while 150 students $(39.3 \%)$ study sports management, and 126 students (33.0\%) study coaching education. 292 students (76.4\%) stated that they took notes during lessons, whereas 90 of them (23.6\%) did not take any notes. Finally, while 50 students (13.1\%) review their lesson notes on a daily basis, 332 of them (86.9\%) stated that they reviewed their lesson notes shortly before a test.

The findings related to mean total test anxiety scale scores and standard deviation values are given in Table 2 .

Table 2. The findings related to mean total test anxiety scale scores and standard deviation values

\begin{tabular}{lccccc}
\hline Test Anxiety & $\mathrm{N}$ & Min. & Mak. & Mean & Ss \\
\cline { 2 - 6 } Scale & 382 & 1.00 & 5.00 & 3.17 & .92 \\
\hline
\end{tabular}

It can be understood from Table 2 that students' levels of test anxiety were moderate (Ort. $=3.17$ ).

$\mathrm{T}$ test findings related to the comparison of mean total test anxiety scale scores in terms of gender are given in Table 3.

Table 3. T test findings related to the comparison of mean total test anxiety scale scores in terms of gender

\begin{tabular}{lcccccc}
\hline & Gender & $\mathrm{N}$ & Mean & $\mathrm{S} . \mathrm{s}$ & $\mathrm{t}$ & $\mathrm{p}$ \\
\cline { 2 - 6 } Test Anxiety Scale & Female & 166 & 3.26 & .90 & 1.784 & .074 \\
& Male & 216 & 3.09 & .92 & & \\
\hline
\end{tabular}

Table 3 indicates that no statistically significant differences were found among mean total test anxiety scale scores in terms of gender ( $>$.05). However, when mean scores are analyzed, it can be observed that female students' level of test anxiety was higher compared to male students (Ort.=3.26).

ANOVA findings related to the comparison of mean total test anxiety scale scores in terms of department are 
given in Table 4.

Table 4. ANOVA findings related to the comparison of mean total test anxiety scale scores in terms of department

\begin{tabular}{|c|c|c|c|c|c|c|c|c|c|c|}
\hline & Department & $\mathrm{N}$ & Mean & Ss & S. of Var. & $\begin{array}{l}\text { Sum of } \\
\text { Squares }\end{array}$ & $\mathrm{sd}$ & $\begin{array}{l}\text { Mean } \\
\text { Square }\end{array}$ & $\mathrm{F}$ & $\mathrm{p}$ \\
\hline $\begin{array}{l}\text { Test } \\
\text { Anxiety }\end{array}$ & $\begin{array}{l}\text { Physical Education and } \\
\text { Sports Teaching }\end{array}$ & 106 & 3.05 & .92 & Among groups & 2.173 & 2 & 1.086 & 1.285 & .278 \\
\hline \multirow[t]{2}{*}{ Scale } & Sports Management & 150 & 3.20 & .95 & Within Groups & 320.338 & 379 & .845 & & \\
\hline & Coaching Education & 126 & 3.23 & .86 & Total & 322.511 & 381 & & & \\
\hline
\end{tabular}

It is evident in Table 4 that no statistically significant differences were observed among mean total test anxiety scale scores in terms of department ( $\mathrm{p}>.05)$. However, it can inferred from mean scores that students studying coaching education had a higher level of test anxiety compared to those studying at other departments (Ort.=3.23).

$\mathrm{T}$ test findings related to the comparison of mean total test anxiety scale scores in terms of note-taking during lessons are given in Table 5.

Table 5. T test findings related to the comparison of mean total test anxiety scale scores in terms of note-taking during lessons

\begin{tabular}{lcccccc}
\hline & Note-Taking during Lessons & $\mathrm{N}$ & $\mathrm{Mean}$ & $\mathrm{Ss}$ & $\mathrm{t}$ & $\mathrm{p}$ \\
\cline { 2 - 6 } Test Anxiety Scale & Yes & 292 & 3.15 & .91 & -.672 & .502 \\
& No & 90 & 3.22 & .95 & \\
\hline
\end{tabular}

Table 5 indicates that no statistically significant differences were observed among mean total test anxiety scale scores in terms of note-taking during lessons ( $p>.05)$. Given the mean scores, however, it can be stated that students who did not take notes during lessons had a higher level of test anxiety compared to those who took notes $($ Ort. $=3.22)$.

ANOVA findings related to the comparison of mean total test anxiety scale scores in terms of frequency of lesson review are given in Table 6.

Table 6. ANOVA findings related to the comparison of mean total test anxiety scale scores in terms of frequency of lesson review

\begin{tabular}{lcccccc}
\hline \multirow{3}{*}{ Test Anxiety Scale } & Lesson Review & $\mathrm{N}$ & Mean & $\mathrm{Ss}$ & $\mathrm{t}$ & $\mathrm{p}$ \\
\cline { 2 - 7 } & Daily & 50 & 3.05 & 1.05 & -.941 & .347 \\
& Shortly before the test & 332 & 3.18 & .89 & & \\
\hline
\end{tabular}

In Table 6, there were no statistically significant differences among mean total test anxiety scale scores in terms of frequency of lesson reviews ( $p>.05$ ). However, as for mean scores, students who reviewed their lesson notes shortly before the exam had a higher level of test anxiety compared to those who reviewed their lesson notes on a daily basis.

\section{Discussion}

In the present study, it was found out that students' levels of test anxiety were moderate. This finding shows that students are generally concerned about intermediate level tests. In a similar study, Bozkurt (2012) also concluded that students' levels of test anxiety were moderate. This finding supports the outcome of the study. However, Şahinler (2018) reported that students' levels of test anxiety were low.

No significant differences were found between female and male students' levels of test anxiety in terms of gender. When similar studies are analyzed, it can be observed that Aba (2018) did not report any significant differences between females and males students' levels of test anxiety. Bozkurt (2012) did not yield any significant differences between female and males students, either. Similarly, Demirci (2018) did not find out any 
significant differences between females and males in terms of test anxiety. Two other similar studies, Piji Küçük (2010) and Karakaş (2013), observed no significant differences between female and male students. All of these studies overlap the findings of the present study in terms of gender.

However, it is also possible to encounter studies which do not support the present study in terms of gender. A study on primary school students demonstrated that there were significant differences between female and male students (Bacanlı \& Sürücü, 2006). Another study on university students, too, displayed significant differences between female and male students in terms of test axiety (Erözkan, 2004). A similar study found out significant differences between female and male students (Duman, 2008). Kavakcı et al. (2011) and Şahinler (2018) also observed significant differences between female and male students in terms of test anxiety. Another study on students indicated that there were significant differences between females and males in terms of test anxiety (Yalçınöz, 2017). It was also reported in another study that there were significant differences between female and male students in terms of test anxiety (Şeftalici, 2017). Finally, a study indicated significant differences between female and male students' levels of test anxiety (Haydargil, 2016).

No statistically significant differences were observed among students' levels of test anxiety in terms of department. This finding shows that the anxiety of the test does not make any difference between the different department students. In a similar vein, Erözkan (2004) reported that no significant differences were observed among students' level of test anxiety in terms of department. This finding supports the outcome of the study.

\section{Results}

The present study demonstrated that students' levels of test anxiety were moderate. In terms of gender, no statistically significant differences were observed between female and male students' levels of test anxiety, demonstrating that test anxiety is not affected by gender. Therefore, it can be stated that female and male students suffer from test anxiety at a similar level.

Similarly, students' departments as a variable did not affect their levels of test anxiety. In other words, students studying at different departments maintained a similar attitude towards test anxiety. Additionally, students' note-taking habits during lessons did not lead to any significant differences in terms of test anxiety. This finding indicates that note-taking is not an important factor when it comes to test anxiety. Finally, it was found out that whether students reviewed their lesson notes on a daily basis or shortly before the test did not result in any significant differences in terms of test anxiety.

As a result, it was determined that test anxiety did not create meaningfulness on variables such as gender, department, follow-up of lesson notes.

\section{References}

Aba, D. (2018). Öğrencilerin sınav kaygısı ile akademik başarı arasındaki cinsiyet farklıllğg. Yüksek Lisans Tezi. Üsküdar Üniversitesi, Sosyal Bilimler Enstitüsü, İstanbul.

Aydın, U., \& Bulgan, G. (2017). Çocuklarda sınav kaygısı ölçeği'nin Türkçe uyarlaması: geçerlik ve güvenirlik, çalışması. Illköğretim Online, 16(2), 860-899. https://doi.org/10.17051/ilkonline.2017.304742.

Bacanlı, F., \& Sürücü, M. (2006). İlköğretim 8. sınıf öğrencilerinin sınav kaygıları ve karar verme stilleri arasındaki ilişkilerin incelenmesi. Educational Administration: Theory and Practice, 45, 7-35.

Bagozzi, R. P., \& Yi, Y. (1988). On the evaluation of structural equation models. Academy of Marketing Science, 16(1), 76-94. https://doi.org/10.1007/BF02723327

Başarır, D. (1990). Ortaokul son sınıf öğrencilerinde sinav kaygısl, durumluk kaygl, akademik başarı ve sinav başarısı arasındaki ilişkiler. Yüksek Lisans Tezi. Hacettepe Üniversitesi, Sosyal Bilimler Enstitüsü, Ankara.

Bozkurt, S. (2012). İlköğretim ikinci kademe öğrencilerinde sinav kaygısı, matematik kaygısı, genel başarı ve matematik başarısı arasındaki ilişkilerin incelenmesi. Yüksek Lisans Tezi. İstanbul Üniversitesi, Sosyal Bilimler Enstitüsü, İstanbul.

Can, G. (1992). Akademik başarısızlık ve önlenmesi. Eskişehir, Anadolu Üniversitesi Yayınları.

Cüceloğlu, D. (1997). İnsan ve davranışı. İstanbul, Remzi Kitapevi.

Demirci, E. (2018). Ergenlerde temel psikolojik ihtiyaçlar irrasyonel inanışları ile mükemmeliyetçilik ve sınav kaygısı arasındaki iliş̧ki. Yüksek Lisans Tezi. İstanbul Arel Üniversitesi, Sosyal Bilimler Enstitüsü, İstanbul. 
Duman, G. K. (2008). İlköğretim 8. sinıf öğrencilerinin durumluk sürekli kaygı düzeyleri ile sinav kaygısı düzeyleri ve ana-baba tutumları arasındaki ilişkinin incelenmesi. Yüksek Lisans Tezi. Dokuz Eylül Üniversitesi, Eğitim Bilimleri Enstitüsü, İzmir.

Erözkan, A. (2004). University student's test anxiety and coping behaviours. Muğla Üniversitesi Sbe Dergisi. 1(12), 13-38.

Geçtan, E. (1993). Psikanaliz ve sonrası. 5. Baskı. İstanbul, Remzi Kitabevi.

Haydargil Özdemir, N. (2016). Mimarlık öğrencilerinin öğrenme stilleri ve sınav kaygısı arasındaki ilişkinin belirlenmesi. Yüksek Lisans Tezi. Zirve Üniversitesi, Fen Bilimleri Enstitüsü, Gaziantep.

Karakaş, A. C. (2013). Paylaşma tutumlarının sınav kaygısı-gelecek kaygısı ile ilişkisi (Sakarya İli Örneği). Journal of the Human and Social Science Researches, 2(1), 135-157.

Kavakcı, Ö., Güler, A. S., \& Çetinkaya, S. (2011). Test anxiety and related psychiatric symptoms. Klinik Psikiyatri, 14, 7-16.

Köknel, Ö. (1989). Genel ve klinik psikiyatri. İstanbul, Nobel Tip Kitapevi.

Nunnally, J. C., \& Bernstein, I. H. (1994). Psychometric theory. New York: Mcgraw Hill.

Piji K. D. (2010). Müzik öğretmeni adaylarının sınav kaygısı, benlik saygısı ve çalgı başarıları arasındaki ilişkinin incelenmesi. Ahi Evran Üniversitesi Eğitim Fakültesi Dergisi, 11(3), 37-50.

Sprelberger, C. D. (2010). State-Trait anxiety inventory. John Wiley \& Sons, Inc. https://doi.org/10.1002/9780470479216.corpsy0943

Şahin, H., Günay, T., \& Batı, H. (2006). İzmir ili bornova ilçesi lise son sınıf öğrencilerinde üniversiteye giriş sinavı kaygısı. Sted Dergisi, 15(6), 107-113.

Şahinler, G. (2018). On İkinci sinıf lise ögrencilerinin mesleki olgunluk ve umut düzeyi ile sinav kaygısı arasındaki ilişkinin incelenmesi. Yüksek Lisans Tezi. Karadeniz Teknik Üniversitesi, Eğitim Bilimleri Enstitüsü, Trabzon.

Şeftalici, B. (2017). Lise son sınıf ögrencilerinde sınav kaygısı ve maneviyat şanlıurfa-viranşehir örneği. Yüksek Lisans Tezi. Çukurova Üniversitesi, Sosyal Bilimler Üniversitesi, Adana.

Şencan, H. (2005). Sosyal ve davranısssal ölçümlerde güvenilirlik ve geçerlik. Ankara, Seçkin Yayınları.

Şimşek, O. F. (2007). Yapısal eşitlik modellemesine giriş, temel ilkeler ve lisrel uygulamaları. Ankara, Ekinoks Yayınları.

Totan, T., \& Yavuz, Y. (2009). Westside sinav kaygısı ölçeğinin türkçe formunun geçerlik ve güvenirlik çalışması. Mehmet Akif Ersoy Üniversitesi, Eğitim Fakültesi Dergisi, 9(17), 95-109.

West, S. G., Finch, J. F., \& Curran, P. J. (1995). Structural equation models with nonnormal variables and remedies. In R. H. Hoyle (Ed.), Structural Equation Modeling: Concepts, Issues and Applications. London: Sage.

Wuest, D., \& Bucher, C. (2006). Foundations of physical education, exercise science and sport. New York: McGraw Hill.

Yalçınöz, V. (2017). Ergenlerin problemli internet kullanımı ile sınav kaygısı düzeylerinin incelenmesi. Yüksek Lisans Tezi. Dokuz Eylül Üniversitesi, Eğitim Bilimleri Enstitüsü, İzmir.

Zorba, E. (2008). Türkiye'de rekreasyona bakış açısı ve gelişimi. Gazi Haber Dergisi, 52-55.

\section{Copyrights}

Copyright for this article is retained by the author, with first publication rights granted to the journal.

This is an open-access article distributed under the terms and conditions of the Creative Commons Attribution license (http://creativecommons.org/licenses/by/4.0/). 